\title{
EDUCATION IN AFGHANISTAN
}

SECTORAL BRIEFING FOR IRC/RAP

April 1996

BACKGROUND:

Before 1912, children took lessons in mosques through BAGHDADI rules to read Qoran and to pray properly. Those who wanted to become religious teachers or preaching leaders followed a graded course of Arabic religious books advised by traditionalists of Islam. The origin of this method goes back to the time of the Abbasid rulers. Later military training and some schools used Turkish influenced approaches.

Formal education began in 1912-13 during King Habibullah, King Amanulla's father, establishing the Habibia School in Kabul( attributed his name), which used a British type of curriculum mostly taught by Indian teachers. A few other similar schools were also opened in the capital city during this time.

In King Amanullah's time, when the Anglo-Afghan wars were over, a new school by the name of Nijat School (Rescue School) was opened, using a German style of curriculum. Later one student of that school shot King Nadir, King Zahir's father who had opened Estiqlal Lycee (Independence Lycee), using a French style curriculum and methodology, in which only children of royal families could enter, dynastic and ethnic favoritism being the practice. During this time several schools were opened in the capital and in some provinces, using mixed curriculums and methodologies, and beginning different trends in education in Afghanistan.

In King Zahir's time many schools were opened and the American type of curriculum and methodologies began to be adapted and then adopted widely. Adult education started using an American (Dr. Block) approach in which emphasis is placed on the phonetic system. New educational institutes and faculties emerged in the Ministry of Education and Kabul University. Yet, centrally controlled system of education prevailed in schools. Even at his time, dynastic and ethnic favoritism in education was in practice. Moreover, urban favoritism was in practic as well. 
In 1973, during Sardar Dauod's government, the curriculum changed twice, influenced by reform policies. Dynastic favoritism was abolished but ethnic and urban favoritism in education still remained in force.

In 1978 when the Soviet-supported government came to power, a grave political and ideological change in the whole education system took place, and a Soviet-oriented system was imposed. Ethnicism emerged widely and viciously and distorted the whole national order.

From 1978 onwards Mujahideen factions in Pakistan uninamously devised a curriculum based on the ideals of Islamic Jehad against the invasion of Afghanistan by the Soviet Red Army, in collaboration with the Education Center For Afghanistan (ECA). Textbooks and learning materials were all printed by UNO (University of Nebrska at Omaha) and were distributed in bulk to all the refugee camps in Pakistan and to all the areas dominated by the mujahideen inside Afghanistan.

In 1992 when the Islamic government came to power, the previous education system in Kabul was stepped over and they chose to adapt the kind of program already developed in the refugee communities in Pakistan.

Education in Afghanistan has traditionally been entirely subsidized by the government, however, from 1966 private. centers for learning foreign languages, university entrance preparation courses, science and fellow science courses, art and music courses, computer courses, etc. on a feecharging basis opened one after the other. But formal education has still retained dependency on the government and now NGO budgets.

\section{THE PRESENT STATE OF EDUCATION:}

Afghanistan is currently split into opposing administration powers, and because of the multi-dimensional conflicts their educational ideals are not the same. It could now be depicted as thus: 
KABUL MINISTRY OF EDUCATION -

It has recently made a new curriculum (for grades 1-6, 7-9, 10-12) and educational policy which was presented in a large meeting attended by the influential ministry staff and the representatives of more than 30 international organizations and NGOs in Kabul in 13 March 1996. In a part of his speech the minister of education referred to a proverb meaning "Yes, destruction is obvious in a place suffering from a storm," and Afghanistan has suffered many storms. At the end of his speech he gave an example of a visit to a school where he saw the children studying without textbooks; he was very sad that even he as a Government Minister could do nothing because of lack of resources.

Curriculum and textbooks presented elicited mixed responses, due to failure of proper'coordination and consultation with the organizations and agencies concerned. Several issues of contention are conspicuous in the already approved curriculum and policy. For instance:

Division of students after grade 9 to natural sciences and social sciences sections, "logic" for boys and" psychology" for girls in the curriculum of grade 12, addition of "Islamic Vision" subject in the curriculum, absence of basic health, environment, disabilities issues in the curriculum, textbook printing, acceptability of the textbooks/curriculum by opposition, duplication of textbooks for grade-3 and other relevant issues were suggested to be considered.

The Ministry of Education has been flexible enough to receive suggestions and comments on the new policy and curriculum and will reconsider it in future meetings.

\section{TALIBAN -}

They do not accept any curricula or textbooks except for the textbooks revised and printed by UNO. Their plan for a new educational policy has not yet been publicly revealed, if indeed they have such a policy.

NGOS -

Their part in delivering educational services has also been aparent in 
Afghanistan in the past as well as in the present. Many international organizations and NGOs have done worthwhile jobs in education before and since 1988 when they were coordinated by ACBAR. Their contributions are vividly recorded in the various ACBAR Directories. However, some of the said organizations have begun closing down and the existing ones have reduced their contributions, which has led some schools to collapse. Currently they are practicing different curricula and methodologies selected or tailored as advised to fit for the targeted regions. Although inter-NGO cooperation is weak, they generally follow the same basic objectives such as to provide basic education for Afghan children and to impart a peace message through curricula content. Curricula is based on student-centered approach conducted by method of: MOTIVATION, PRESENTATION, DRILLS, FEEDBACK, and are evaluated by tests and examinations.

The influential characters in education delivered by NGOs are Ms. Nancy Dupree in particular, and the representatives of the main NGOs for the ACBAR Education Sub-committee, in general. The government Ministry of Education academic officials, the Provincial Shuras, the commanders, and some educationists inside or outside of Afghanistan are influential as well.

NGOs usually maintain discussions with the government and parties in connection to approval of curriculum, policies, and community contributions all along the cycle of the schools projected. Agreements and mutual cooperation contracts are signed with them.

Lack of appropriate inter-agency coordination and inconsistent cooperation between the parties concerned, interrupted funding, unpredictable restrictions imposed by regional commanders, misinterpretation of some programs to the community, unforcastable clashes between the warring groups, absence of body to print textbooks, inadequate teacher supply, social organization of communities on power and patronage, widespread poverty, limited experience of urban-base personnel of NGOs with rural community development and limited opportunities for community mobilization may often cause difficulties, risks and constraints.

\section{PRIMARY EDUCATION SUPPORT:}


TEACHERS SALARIES -

In ACBAR Educational Sub-committee meetings, the salary level is recommended based on the cost of living for an average seven-member family. Rs. 5000 was accepted as its total cost for one month. A certain percentage of the total cost was agreed to be the minimum and maximum salary. The remaining percentage will be covered from other sources. A reasonable salary for the academic year 1996-97 is based on a nation-wide market basket survey which will be done by a designed questionnaire. (A scale sheet is enclosed for detail.)

\section{SCHOOL EQUIPMENT -}

With regard to equipment, only revised UNO printed textbooks, teaching materials, tents and floor coverings are given to the schools projected by NGOs. Infra-structure is curently reckoned as part of the community commitment. Other items of support are indicated by annexed charts in the NGOs Education Work Plan for 1995, , but future supports will be specified in plans that will be produced annually, by ACBAR Education Sub-Committee or another appropriate body. The 1995 plan largely reflects work which is practical and ongoing.

\section{CURRENT STATUS-}

In the present circumstances, neither the government nor the community can afford to run schools at their own expense. They definitely depend on donors to provide assistance in funding, expertise, counselling and guidance until the people gain a stable living condition and a functioning government.

Almost all over Afghanistan now the vast majority of people value and appreciate schools to educate their children, but they are not in a position to pay fees. They reckon it to be the obligation of the government to provide them with such services. Some people may selectively pay fees only when their children are trained in a highly favored skill. Typically the people take it for granted that schools are merely means to literacy and it is just exceptional to them that only few boys take the avenue up to become important men in government positions. 
6

\section{OPINIONS:}

Contacts and exchange of views with some university professors, school teachers, and educationists of consistent experience in educational organizations revealed that education is a valuable avenue for addressing community adversities provided the schools follow a unified education system led by a strong national central education body. Since it is not applicable at present, a reasonable curriculas (locally and universally acceptable) could be applied. Changes to curriculums, textbooks, methodologies, materials and so forth could be sought only through valid researches and scientific analysis of the society in collaboration with the concerned and affiliated institutions. Even amendments and changes in the programs and policies of education need to comply with the guidelines based on the general consensus of the country.

\section{MY OPINION ON THE APPROACH RAP SHOULD FOLLOW:}

Taking in view the above-mentioned background, opinions and RAP's experience in the past, I should suggest that IRC/RAP would better fund formal education in the areas where schools received support from international donors or the governments in the past but now due to discontinuation of support they have collapsed or are about to collapse, giving priority for girls and boys primary education in rural areas. This support may call for close contacts with $S C A$ and $A D A$, the two main agencies supporting large number of schools in rural areas, ranging some 25 to $30 \%$ of all primary schools in the country. Support may include textbooks, school and teacher supplies, training and salary support. Salary support can be based on the scale provided by $A C B A R$. Besides this, in consultation with the responsibles of local education, an hour a week or so can be scheduled for co-existence or social justice lessons to all classes of each school in order to have complexities eliminated and a sense of national unity could be created among the new generation. To this end, I believe, UNICEF APO (Afghan Program Office in Peshawar) can best help, because some valuable materials for the said topics have already been developed. Also in the structure of each school a continual contact with parents and 


\section{7}

community can be envisaged to encourage the community participation in order to ensure their contribution towards a sustainable education. ( A scale of cost per student per term for the grades 1 -9, being extracted from the new educational plan of the Ministry of Education and from interviews with students parents, is also annexed to this.)

$R A P$ can check the curriculum of the proposed schools and to make sure that it is locally and universally acceptable (prepared on the basis of scientific norms and standards). Curricula of an extremist nature should not be funded by RAP, because RAP should concentrate on giving humanitarian assistance to underserved rural communities. Meanwhile, the proposed schools in general should fit into the educational framework marked by the long educational traditions already accepted all over Afghanistan. Equity in delivering educational services to rural areas should also be regarded.

Gathered by:

Abdul Ghias Naubahar

Technical Advisor for Education

IRC / RAP

\section{REFERENCES:}

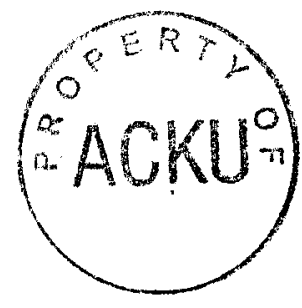

- ACBAR, Resource \& Information Center, EDUCATION Files \& General Directory.

- Dr. Y. Nuristani, Chairman Educataion Sub-committee, ACBAR.

- Mr. Fahim, Officer Resourse \& Information Center, ACBAR.

- Mr. Eric Vander Lee, Education Officer, IRC/RPA.

- UNICEF, APO, Peshawar.

- Dr. S. Sultan Sha Humam, Anthropology Prof. Kabul University, now Principal of IRC/FETT funded school in Para Chinar. 
EDUCATIONAL PLAN OF GENERAL SCHOOLS: EDUCATION PROGRAM FOR 1996 (Kabul)

\begin{tabular}{|c|c|c|c|c|c|c|c|c|c|c|c|c|c|c|c|}
\hline \multirow[b]{2}{*}{ SUBJECTS } & \multicolumn{3}{|c|}{ Ist Grade } & \multicolumn{3}{|c|}{ 2nd grade } & \multicolumn{3}{|c|}{$\overline{~ M i d d l e ~}$} & \multicolumn{3}{|c|}{ 2ndary } & \multicolumn{3}{|c|}{ 2ndary } \\
\hline & 1 & 2 & 3 & 4 & 5 & 6 & 7 & 8 & 9 & 10 & 11 & 12 & 10 & 17 & 12 \\
\hline H. Koran & 2 & 2 & 2 & 2 & 2 & 2 & 2 & 2 & 2 & & & & & & \\
\hline Theology & 2 & 2 & 2 & 2 & 2 & 2 & 2 & 2 & 2 & & & & & & \\
\hline Is. sight & & & & & & & & & & 2 & 2 & 2 & 2 & 2 & 2 \\
\hline Comm.Koran & & & & & & & & & & & 2 & & & 3 & \\
\hline Hadis(Trad.) & & & & & & & & & & 2 & & & 3 & & \\
\hline Beliefs & & & & & & & & & & & & 2 & & & 3 \\
\hline Arabic & & & & & & & 3 & 3 & 3 & & & & & & \\
\hline M.Tongue & 10 & 10 & 10 & 8 & 8 & 8 & 5 & 5 & 5 & 3 & 3 & 3 & 5 & 5 & 5 \\
\hline 2nd Langu. & & & & 4 & 4 & 4 & 3 & 3 & 3 & 2 & 2 & 2 & 4 & 4 & 4 \\
\hline F. Langu. & & & & & & & 3 & 3 & 3 & 2 & 2 & 2 & 3 & 3 & 3 \\
\hline Calligraphy & 2 & 2 & 2 & 1 & 1 & 1 & & & & & & & & & \\
\hline Math/Algebr & 6 & 6 & 6 & 6 & 6 & 6 & 3 & 3 & 3 & 3 & 2 & 2 & 2 & 2 & 2 \\
\hline Geometry & & & & & & & 2 & 2 & 2 & 3 & 3 & 3 & & & \\
\hline Trigonometry & & & & & & & & & & & 1 & 1 & & & \\
\hline Science \& $H$ & & & & 3 & $\overline{3}$ & 3 & & & & & & & & & \\
\hline Chemistry & & & & & & & 2 & 2 & 2 & 5 & 5 & 5 & 1 & 1 & 1 \\
\hline Biology & & & & & & & 2 & 2 & 2 & 5 & 5 & 5 & 1 & 1 & 1 \\
\hline Physics & & & & & & & 2 & 2 & 2 & 5 & 5 & 5 & 1 & 1 & 1 \\
\hline So. Studies & & & & 2 & 2 & 2 & & & & 2 & 2 & 1 & & & \\
\hline History & & & & & & & 2 & 2 & 2 & & & & 5 & 5 & 5 \\
\hline Geography & & & & & & & 2 & 2 & 2 & & & & 5 & 5 & 5 \\
\hline Civics & & & & & & & & & & & & & 2 & 2 & 1 \\
\hline H.Econo. G. & & & & & & & & & & 1 & 1 & & 1 & 1 & \\
\hline Agr.\& Art.B & & & & & & & & & & 1 & 1 & & 1 & 1 & \\
\hline $\begin{array}{l}\text { Drawg Arts } \\
\text { \& Prac.w }\end{array}$ & 1 & 1 & 1 & 1 & 1 & 1 & 2 & 2 & 2 & & & & & & \\
\hline $\begin{array}{l}\text { Psycho. G. } \\
\text { Logic } \quad B\end{array}$ & & & & & & & & & & & & $\begin{array}{l}2 \\
2\end{array}$ & & & $\begin{array}{l}2 \\
2\end{array}$ \\
\hline Phys. Edu. & 1 & 1 & 1 & 1 & 1 & 1 & 1 & 1 & 1 & 1 & 1 & 1 & 1 & 1 & 1 \\
\hline Refinement & & & & & & & & & & & & & & & \\
\hline $\begin{array}{l}\text { Total no. of } \\
\text { periods per } \\
\text { term }\end{array}$ & 24 & 24 & 24 & 30 & 30 & 30 & 36 & 36 & 36 & 36 & 36 & 36 & 36 & 36 & 36 \\
\hline
\end{tabular}




\section{STUDENT MATERIALS COST PER TERM (9 months):}

1. BASIC LEVEL-I (Grades 1 - 3):

(One-teacher-for-each-class system)

Textbooks:

\begin{tabular}{||l|c||}
\hline NAMES OF TEXT & UNIT PRICE \\
\hline \hline 1. Koran & Rs. 14 \\
\hline 2. Theology & 14 \\
\hline 3. M. Tongue & 14 \\
\hline 4. Math & 14 \\
\hline 5. Calligraphy & 14 \\
\hline 6. Art \& Handw. & 16 \\
\hline 7.Phys. Edu. & 10 \\
\hline \hline TOTAL: & Rs. 96 \\
\hline
\end{tabular}

Stationery:

\begin{tabular}{||l|l|l|l|c||}
\hline NAMES OF ITEM & COST PER WEEK & COST PER TERM & UNIT PRICE & AMT.Rs \\
\hline \hline Notebooks, Paper & 4 sets & 36 sets & 5 & 180 \\
\hline Pens \& Pencils & 5 & 45 & 2 & 90 \\
\hline Crayons \& Ink & 1 set & 9 & 10 & 90 \\
\hline Additionals & Rs. 10 & & 10 & 90 \\
\hline \hline TOTAL COST & & & & Rs. 450 \\
\hline
\end{tabular}

TOTAL COST PER STUDENT PRER TERM: Rs.96+450=

NOTE: This approximation of cost is extracted from Educational Plan and Policy Ministry of Education, Kabul, and interviews with students' parents, and can be valid for 1996-97. 
BASIC LEVEL - II (Grades 4-6):

(One-teacher-for-easch-subject system)

TEXTBOOKS:

\begin{tabular}{||l|c|}
\hline \hline $\begin{array}{l}\text { NAME OF } \\
\text { TEXTS }\end{array}$ & $\begin{array}{l}\text { UNIT } \\
\text { PRICE }\end{array}$ \\
\hline 1. H. KORAN & Rs. 14 \\
\hline 2. Theology & 14 \\
\hline 3. M. Tongue & 14 \\
\hline 4. 2nd Lang. & 14 \\
\hline 5. Math & 14 \\
\hline 6. Science\&H. & 14 \\
\hline $\begin{array}{l}\text { 7. Social' } \\
\text { Studies- His., } \\
\text { Geography }\end{array}$ & 14 \\
\hline 8. Calligraphy & 14 \\
\hline $\begin{array}{l}\text { 9. Drawing, } \\
\text { Local Crafts }\end{array}$ & 14 \\
\hline 10. Phys. Edu. & 7 \\
\hline \hline TOTAL: & Rs.133 \\
\hline \hline
\end{tabular}

STATIONERY:

\begin{tabular}{||l|l|l|l|l||}
\hline \hline NAMES OF ITEMS & $\begin{array}{l}\text { COST PER } \\
\text { WEEK }\end{array}$ & $\begin{array}{l}\text { COST PER } \\
\text { TERM }\end{array}$ & $\begin{array}{l}\text { UNIT } \\
\text { PRICE }\end{array}$ & $\begin{array}{l}\text { AMOUNT } \\
\text { RUPEES }\end{array}$ \\
\hline \hline 1. Notebooks, paper & 5 sets & 45 sets & Rs. 5 & Rs.225 \\
\hline 2. Pens, pencils & 7 & 63 & 2 & 126 \\
\hline 3. Crayons, material & 2 sets & 18 & 15 & 270 \\
\hline 4. Additionals & Rs.12 & 108 & & 108 \\
\hline \hline TOTAL COST & & & & Rs. 729 \\
\hline
\end{tabular}

TOTAL COST PER STUDENT PER TERM: $R s .133+729=\underline{\text { Rs. } 862}$ 
SECONDARY LEVEL - 1 (Grades 7 -9):

TEXTBOOKS:

\begin{tabular}{||l|c||}
\hline NAMES OF TEXT & UNIT PRICE \\
\hline \hline 1. H. Koran & Rs. 14 \\
\hline 2. Theology & 14 \\
\hline 3. Arabic Langu. & 14 \\
\hline 4. M. Tongue & 14 \\
\hline 5. 2nd Language & 14 \\
\hline 6. Foreign Lang. & 14 \\
\hline 7. Math & 14 \\
\hline 8. Geometry & 14 \\
\hline 9. Physic's & 14 \\
\hline 10. Chemistry & 14 \\
\hline 11. Biology & 14 \\
\hline 12. History & 14 \\
\hline 13. Geography & 14 \\
\hline 14. Prac. works & 14 \\
\hline Local Crafts) & \\
\hline \hline 15. Phys. Edu. & 10 \\
\hline TOTAL: & Rs. 206 \\
\hline STATONER:
\end{tabular}

STATIONERY:

\begin{tabular}{||l|l|l|l|c||}
\hline NAMES OF 1TEM & COST PER WEEK & COST PER TERM & UNIT PRICE & AMOUNT \\
\hline \hline Notebooks,paper & 5 sets & 45 sets & Rs. 5 & 225 \\
\hline Pens \& Pencils & 7 & 63 & 2 & 126 \\
\hline Materials & 10 Rs. & 360 Rs. & & 360 \\
\hline Additionals & 10 Rs. & 360 Rs. & & 360 \\
\hline \hline TOTAL: & & & & Rs. 1071 \\
\hline
\end{tabular}

TOTAL COST PER STUDENT PER TERM: Rs.206 + $1071=\underline{\text { Rs.1,277. }}$ 